\title{
Analysis of the Impact of the Omnibus Law on Society in Terms of Law Number 13 of 2003 Concerning Manpower and Law Number 11 of 2020 Concerning Work Copyright
}

\author{
Jefri Rahmansyah Putra', Sriono ${ }^{2}$, Bernat Panjaitan ${ }^{3}$ \\ 1,2,3 Law Study Program, Faculty of Law, Labuhanbatu University, Indonesia \\ Sriono.mkn@gmail.com
}

\begin{abstract}
Government prepares Law Copyright Labor by using the concept of Omnibus Law, to be used as a scheme to build the economy in order to attract investors to invest in Indonesia. Law Number 11 of 2020 concerning Job Creation has several clusters, one of which regulates employment as stated in the previous Law, namely Law Number 13 of 2003 concerning Manpower. In the employment cluster, the Government seeks to harmonize the 3 laws so that they are in line so as to provide a space for investors to open their businesses without worrying about overlapping regulations and causing losses to investors. This research menuse normative juridical methods, the concept of the Omnibus Law So far it is not clearly regulated in Law Number 11 of 2020 concerning Job Creation. The government is trying to implement the omnibus law to create jobs. But it is not balanced with regulatory substances that are able to avoid conflicts that have occurred so far. This Job Creation Act still has many weaknesses. This problem exists in changes to the provisions for leave, giving severance pay and others. These changes further narrow the space for workers / laborers to fight for their rights.
\end{abstract}

Keywords

employment; omnibus law; worker / labor rights

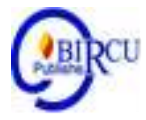

\section{Introduction}

Labor According to Law no. 13 of 2003 Article 1 paragraph 2 states that: "Labor is anyone who is capable of doing work to produce goods and or services either to meet their own needs or for the community." In Law No. 13 of 2003 stipulates that the use of the term worker is always followed by the term labor, which indicates that this Law defines the term with the same meaning. In Article 1 number 3 of Law no. 13 of 2003 concerning Manpower, provides understanding. "A worker / laborer is anyone who works and receives wages or other forms of remuneration." From this understanding, it can be seen that some of the elements inherent in the term worker or laborer are as follows (Agus Midah, 2010):

a) Everyone who works (labor force or not but must work)

b) Receiving compensation / wages as remuneration for the implementation of the work.

Prior to the U ndang- $U$ ndang Copyright Labor, the omnibus law is relatively less familiar in the ears of the people of Indonesia. This is reasonable, considering that the Job Creation Law is the first omnibus law passed in Indonesian law. The Omnibus Law itself became known to the public for the first time in the country since it was mentioned in President Jokowi's inauguration speech in his second term in October 2019. The ratification of the Job Creation Act by the Indonesian Parliament was responded to by massive demonstrations in a number of regions. Not infrequently, demonstrations lead to chaos. The base of his pontificate is mainly related to the changes in the articles of employment. (President Jokowidodo Speech, 2019) 
From several previous articles, we have discussed the omnibus law, which discusses the Omnibus Law, which is the concept of making regulations that combines several rules with different regulatory substances into a large rule that functions as an umbrella act. However, the existence of laws - laws that lead to the results of the Omnibus Law as an umbrella legislation would cause problems regarding his position as Law No. 12 of 2011 which regulates the formation of laws and regulations does not recognize the term Omnibus Law. However, the method of drafting the Omnibus Law Law must still refer to Law No. 12 of 2011 (Dhaniswara K Hardjono, 2020). There are also those who discuss that there are 3 (three) Omnibus law to be made, namely the employment copyright bill, Taxation Bill, and Community Empowerment Bill. The Omnibus Law will replace part or all of the existing laws that are related to the cluster of omnibus laws. The obstacle faced in the formation of the omnibus law is that the members of the DPR do not yet understand in drafting the omnibus law so that special attention is needed and the density of the agenda of the members of the DPR can be a factor inhibiting the slow formation of the omnibus law (Adhi Setyo Prabowo \& et al, 2013).

Workers or laborers as citizens have equal position in the law, the right to get decent work, express opinions, gather in one organization, and establish and become members of a trade / labor union. From the opinion of several experts in Labor Law in his book Chapter XIV "Principles of Labor Law" according to Mr. The law states PERB Molenaar u Ruhan is a part of the law essentially governs the relationship between workers and employers, between workers primarily workers and between workers with a ruler. (Kansil CST, 2002). Meanwhile, Prof. Iman Soepomo said that the Labor Law is a set of regulations, both written and unwritten, which relate to an incident where someone works for another person and receives a wage. (Iman Soepomo, 2003). Basically, development is an effort to create prosperity and welfare of the people. Therefore, development must be carried out fairly and evenly so that it can be enjoyed by all people (Bernat Panjaitan, 2016).

In terminology, omnibus comes from Latin which means for everything. In a legal context, the omnibus law is a law that can cover all or one law that regulates many things. The word omnibus is also used in the Swiss motto or motto, namely "unus pro omnibus, omnes pro uno" which means "one for all, all for one" which symbolizes Switzerland as a country that loves diversity and pluralism. Although it is considered a new legal product in Indonesia, omnibus law is commonly used by countries that adhere to the common law legal system. In the United States (US) the omnibus law is known as the omnibus bill. In the US legal system, the omnibus bill is a complex regulatory process and takes a long time to resolve because it contains a lot of material even though the subject, issue and program are not always interrelated. Vietnam and the Philippines are two countries in Southeast Asia that have already practiced the omnibus law. Vietnam is considered successful in attracting a lot of investment after the government provided various facilities for investors in various sectors, such as incentives, tax exemptions, and permits. These conveniences were provided after the issuance of the omnibus law.

Omnibus law means rules made across sectors. This allows the DPR to pass the omnibus law amend several laws at once. Amendments to several old regulations in a package of laws made the omnibus law later referred to as the broomstick law. The new Job Creation Law passed by the DPR regulates at least 11 clusters, including simplification of business licensing, investment requirements, employment, ease of empowering MSMEs, ease of doing business, support for innovation research, government administration, imposition of sanctions, land acquisition, investment and government projects, and the last one is the economic area. So that in practice, the ratification of one Act in the form of the Job Creation Omnibus Law immediately amends several laws at once. However, so far the 
most polemic has emerged, namely in the amendments related to labor, namely Law Number 13 of 2003 concerning Manpower. (Khakim, 2003).

In the labor sector, the government amended, abolished, and added articles related to the Manpower Law such as wages, leave schemes, severance pay, working hours, layoff regulations, and so on. This law is intended to streamline regulation in terms of numbers. In addition, simplifying regulations to make it more targeted. In his book entitled "Omnibus Law and Its Application in Indonesia" according to Prof. Dr. Jimly Asshiddiqie Omnibus Law is a concept that formally combines (amendments) several laws and regulations into one form of new law. This is done to overcome overlapping regulations and reduce problems in the bureaucracy, which are considered to hinder the implementation of the necessary policies (Jimly Asshidiqie, 2021). The concept of the omnibus law or also known as the omnibus bill itself is generally used in countries that adhere to the common law system, such as the United States in making regulations. So, the Omnibus Law on Employment Creation means a new Law that combines regulations and cuts several articles from the previous law including articles on labor into simpler legislation. With the existence of this Job Creation Omnibus Law, Law Number 13 of 2003 concerning Manpower (Manpower Law) is no longer valid.

The labor cluster in the Omnibus Law on the Job Creation Act received the most criticism because it was considered detrimental to workers or laborers. Previous employment issues were regulated in Law Number 13 of 2003 concerning Manpower. Party workers believe their rights under the Act Employment will be further reduced if the Law of Copyright Works Omnibus Law was signed by the president and then executed. The two rules regarding the survival of these workers do have differences. The differences include the rights, obligations and protections of workers. Therefore the aim of this paper is to examine how the impact of the Omnibus law on society in terms of Law Number 11 of 2020 concerning Job Creation. (Prints, 2000).

\section{Research Methods}

The research method used in this research is to use the normative juridical method, which refers to the provisions of positive laws and regulations in Indonesia, among the laws and regulations on Law No. 13 of 2003 which changed to Bill No. 11 of 2020 on copyright. work by knowing the procedures for working copyright law and making it a guide in solving problems that have an impact on society. In this study refers to secondary data research. Thus there are main activities that will be carried out in carrying out this research, namely library research, which is obtained through literature, by reviewing, analyzing, and managing the literature on legislation by researching through articles related to the problem to be examined (Soerjono Soekanto \& Sri Mahmudji, 2003).

\section{Discussion}

\subsection{The Differences of Law Number 11 Year 2020 about the Copyright Working with Law Employment No. 13 of 2003 \\ a. Break Time}

\section{Manpower Act Number 13 of 2003}

The provisions in Article 79 explain:

a) Weekly break for 1 (one) day for 6 (six) working days in 1 (one) week or 2 (two) days for 5 (five) working days in 1 (one) week 
b) A long break of at least 2 (two) months and implemented in the seventh and eighth year, respectively 1 (one) month for workers / laborers who have worked for 6 (six) years continuously at the same company with the provisions of workers / The worker is no longer entitled to his annual rest within the current 2 (two) years and thereafter applies to every multiple of the 6 (six) years working period.

\section{Law Number 11 of 2020 concerning Job Creation}

a) Weekly break for 1 (one) day for 6 (six) working days in 1 (one) week.

b) The Omnibus Law on Employment Creation does not include a two-month long break after six consecutive years of service at the same company.

b. Wages are based on Unit Yield and Time

1. Employment Law No. 13 of 2003

There is no setting regarding wages based on the unit of yield and time.

\section{Law Number 11 of 2020 concerning Job Creation}

It is a revision of articles 88 and 89 by inserting points in article $88 \mathrm{~B}$ :

1). Wages are determined based on:

a. unit of time and / or

b. unit of return.

2). Further provisions regarding wages based on time unit and / or unit yield as referred to in paragraph (1) shall be regulated in a Government Regulation.

\section{c. Provincial, District and City Minimum Wages}

\section{Employment Law No. 13 of 2003}

The provisions in Article 89 explain:

The minimum wage as referred to in Article 88 paragraph (3) letter a may consist of:

a. minimum wage by province or district / city

b. minimum wage by sector in the province or district / city.

\section{Law Number 11 of 2020 concerning Job Creation}

It is a revision of articles 88 and 89 by inserting points in article $88 \mathrm{C}$ :

1. The governor is obliged to determine the provincial minimum wage.

2. The governor can set the district / city minimum wage with certain conditions.

3. The minimum wage as referred to in paragraph (1) and paragraph (2) shall be determined based on economic and labor conditions.

4. Certain conditions as referred to in paragraph (2) include regional economic growth and inflation in the regency / city concerned.

5. The district / city minimum wage as referred to in paragraph (2) must be higher than the provincial minimum wage.

6. The economic and employment conditions as referred to in paragraph (3) shall use data sourced from the authorized institution in the field of statistics.

7. Further provisions regarding the procedure for determining the minimum wage as referred to in paragraph (3) and certain conditions as referred to in paragraph (4) shall be regulated in a Government Regulation.

Law Number 11 Year 2020 About Copyright Work Omnibus Law also regulates the wages of workers of SMEs in Article $90 \mathrm{~B}$ :

1. The provisions of the minimum wage as referred to in Article 88C paragraph (1) and paragraph (2) are exempted for Micro and Small Enterprises. 
2. Wages for Micro and Small Enterprises are determined based on an agreement between the entrepreneur and the worker / laborer in the company.

3. The wage agreement as referred to in paragraph (2) shall be at least a certain percentage of the average public consumption based on data sourced from the authorized institution in the field of statistics.

4. Further provisions regarding wages for Micro and Small Enterprises are regulated by Government Regulations.

\section{d. Rights Compensation Money}

1. Employment Law Number 13 Year 2003 Article 156 paragraph 4:

The compensation money that should be received as referred to in paragraph (1) includes

a) annual leave that has not been taken and has not failed

b) Return costs or fees for workers / laborers and their families to the place where the workers / laborers are accepted to work

c) Housing compensation as well as medication and care is set at $15 \%$ (fifteen percent) of the severance pay and / or service pay for those who meet the requirements.

d) Other matters stipulated in the work agreement, company regulations or collective labor agreement.

\section{Law Number 11 of 2020 concerning Job Creation}

The compensation money that should be received as referred to in paragraph (1) includes:

a) annual leave that has not been taken and has not failed

b) Return costs or fees for workers / laborers and their families to the place where the workers / laborers are accepted to work

c) Other matters stipulated in the work agreement, company regulations or collective labor agreement.

Amendments were also made to the Omnibus Law on Job Creation, by removing the sentence 'at most' in article 156 paragraph two. This article regulates the amount of severance pay or compensation money received by workers.

\section{e. Social Security}

\section{Employment Law No. 13 of 2003}

a). Article 167 paragraph 5

In the event that the entrepreneur does not include workers / laborers who have experienced termination of employment due to retirement age in the pension program, the entrepreneur is obliged to provide the worker / laborer with severance pay of 2 (two) times the provisions of Article 156 paragraph (2), the reward for the period of service of 1 (one ) times the provisions of Article 156 paragraph (3) and compensation for rights according to the provisions of Article 156 paragraph

b). Art 184

Anyone who violates the provisions as referred to in Article 167 paragraph (5), will be subject to imprisonment for a minimum of 1 (one) year and a maximum of 5 (five) years and / or a fine of at least IDR 100,000,000.00 (one hundred million rupiah). and a maximum of Rp. 500,000,000.00 (five hundred million rupiah). 


\section{Law Number 11 of 2020 concerning Job Creation}

The new regulation revises Law No.13 / 2003 by removing articles 167 and 184. The Omnibus Law on Job Creation also revises the types of social security provided to workers by adding job loss benefits. This provision revises Law Number 40 of 2004 concerning the National Social Security System.

\section{f. Reasons for Termination of Employment (PHK)}

\section{U ndang- U ndang Employment No. 13 of 2003}

The provisions explain several things that can cause layoffs, namely the company goes bankrupt, loses, changes status, violates work agreements, makes mistakes, is absent, and resigns.

\section{Law Number 11 of 2020 concerning Job Creation}

This regulation revises articles 154 and 155 to include article $154 \mathrm{~A}$ which explains that termination of employment can occur because:

a) Companies carry out a merger, consolidation, acquisition or separation of companies.

b) the company performs efficiency

c) the company closed because the company suffered a loss

d) the company closed due to force majeure

e) the company is in a state of postponement of debt payment obligations

f) bankrupt company

g) the company commits an act that is detrimental to the worker / laborer

h) the worker / laborer resigns on his own accord

i) workers / laborers are absent

j) The worker / laborer violates the provisions stipulated in the work agreement, company regulations, or collective work agreement.

k) The workers / laborers are detained by the authorities.

1) Workers / laborers experience prolonged illness or disability due to work accidents and cannot carry out their work after exceeding the 12 (twelve) month limit

m) workers / laborers enter retirement age, or

n) Worker / laborer dies.

\section{g. Unspecified work agreement (PKWT)}

\section{Employment Law No. 13 of 2003}

This rule does not regulate PKWT, but regulates the length of a worker contract in article 59:

1). A work agreement for a specified period of time can only be made for a certain job which according to the type and nature or activity of the work will be completed within a certain time, namely:

a) a one-time job or a temporary one

b) work which is estimated to be completed in the not too long period of time and a maximum of 3 (three) years

c) jobs that are seasonal in nature, or

d) Work related to new products, new activities, or additional product that are still in trial or exploration.

2). A work agreement for a specified period of time cannot be made for work that is permanent in nature.

3). The work agreement for a specified period of time can be extended or renewed. 
4). A work agreement for a specified period of time which is based on a certain period of time can be concluded for a maximum of 2 (two) years and may only be extended 1 (one) time for a maximum period of 1 (one) year.

\section{Law Number 11 of 2020 concerning Job Creation}

This provision revises article 59 by adding PKWT to:

1). A work agreement for a specified period of time can only be made for a certain job which according to the type and nature or activity of the work will be completed within a certain time, namely:

a) one-time job or a temporary one

b) work that is estimated to be completed in the not too long time

c) seasonal work

d) work related to new products, new activities, or additional products that are still in trial or investigation, or

e) Work of which type and nature or activity are not permanent.

2). A work agreement for a specified period of time cannot be made for work that is permanent in nature.

$3)$. A work agreement for a specified period of time that does not meet the provisions as referred to in paragraph (1) and paragraph (2), then by law it becomes a work agreement for an indefinite period of time.

4). Further provisions regarding the type and nature or activity of work, period of time, and deadline for extension of a work agreement for a specified period of time shall be regulated in a Government Regulation.

\section{h. Length of Overtime}

1. Employment Law No. 13 of 2003

Article 78 paragraph 1 point $b$ :

Overtime can only be done for a maximum of 3 (three) hours in 1 (one) day and 14 (fourteen) hours in 1 (one) week.

\section{Law Number 11 of 2020 concerning Job Creation}

This rule revises the previous to:

Overtime can only be done for a maximum of 4 (four) hours in 1 (one) day and 18 (eighteen) hours in 1 (one) week.

\section{i. Use of Foreign Workers}

\section{Employment Law No. 13 of 2003}

Article 42:

1) Every employer who employs foreign workers must have a written permit from the Minister or an appointed official.

2) Individual employers are prohibited from employing foreign workers.

3) The obligation to have a license as referred to in paragraph (1) does not apply to representatives of foreign countries who employ foreign workers as diplomatic and consular employees.

4) Foreign workers can be employed in Indonesia only in an employment relationship for a certain position and for a certain time.

5) Provisions regarding certain positions and a certain time as referred to in paragraph (4) shall be stipulated by a Ministerial Decree. 
6) Foreign workers as referred to in paragraph (4) whose working period has expired and cannot be extended can be replaced by other foreign workers.

\section{Law Number 11 of 2020 concerning Job Creation}

Revised Law Act Employment No. 13 of 2003 Article 42 to:

1) Every employer who employs foreign workers is obliged to have a plan for the use of foreign workers which is approved by the Central Government.

2) Individual employers are prohibited from employing foreign workers.

3) The provisions referred to in paragraph (1) do not apply to:

a) directors or commissioners with certain share ownership or shareholders in accordance with the provisions of laws and regulations

b) diplomatic and consular employees at representative offices of foreign countries, or

c) foreign workers required by the Employer in the types of production activities that have stopped due to emergencies, vocational, start-up companies (start-ups), business visits, and research for a certain period of time.

4) Foreign workers can be employed in Indonesia only in an employment relationship for a certain position and for a certain time and have the competence according to the position to be occupied.

5) Foreign workers are prohibited from holding positions in charge of personnel.

6) Provisions regarding certain positions and certain times as referred to in paragraph (4) and paragraph (5) shall be regulated in a Government Regulation.

\subsection{Omnibus Law Purpose}

Based on the P origin 3 U ndang- U ndang Number 11 Year 2020 About Copyright Employment, said that the purpose of made Law Copyright Employment is to create job opportunities as possible for the people of Indonesia evenly. This is done in order to fulfill a decent living through the following points:

a) Convenience, Protection and Empowerment of MSMEs and Cooperatives;

b) Improvement of the investment ecosystem;

c) Ease of doing business;

d) Increasing the protection and welfare of workers; and

e) Central Government investment and acceleration of national strategic projects.

\subsection{Law Omnibus Benefits}

With the existence of the Omnibus Law related to Job Creation, there are several benefits that are obtained:

\section{a. Simplification and harmonization of regulations and permits}

The big issue in the Job Creation Omnibus Law currently lies in simplifying business licensing. With the Omnibus Law on Job Creation, it is hoped that business licensing will be simpler but clearer.

\section{b. Achievement of quality investment}

Investment aims to spur economic growth. To achieve this, investment needs to be increased in line with the increase in Indonesia's competitiveness internationally. This is also in line with the first point, namely simplification of the licensing process. The licensing process is simplified and made risk-based. In addition, standards are required in the licensing process as well as costs. 


\section{c. Creating quality employment and worker welfare in a sustainable manner}

As mentioned in point 2 above, there is an increase in Indonesia's competitiveness internationally. For that, we need quality employment opportunities. It is also necessary to reduce the unemployment rate. The Job Creation Act is expected to have a positive impact, especially in terms of increasing the economic value and standard of living of the community.

\section{d. Empowerment of MSMEs}

The Omnibus Law for Job Creation will have a higher productivity impact on micro businesses. That way, the empowerment of MSMEs can be achieved in line with the increase in Indonesia's competitiveness. In essence, the Omnibus Law or Job Creation provides benefits both to the Indonesian economy, business actors, and workers. With the Omnibus Law Cipta Jobs, it is hoped that productive jobs can be created. A healthy work environment will be created over time thanks to the Omnibus Law.

\subsection{The Impact of the Omnibus Law on Society / Workers}

a. Longer working hours and overtime

The substance of the Job Creation Law changes working hours, namely the elimination of the provisions of five working days and two weekly rest days. In the provisions of Article 79 of the Ciptaker Law paragraph 1b, it is stated that the weekly rest is 1 day for 6 working days. Apart from working for 6 days, workers are also forced to extend overtime. In the Job Creation Law it is stated that overtime is done 4 hours in 1 day and 18 hours in a week. Overtime is extended from the provisions of Article 78 of the Manpower Act 32/2003, which states that overtime can only be done a maximum of 3 (three) hours in 1 (one) day and 14 (fourteen) hours in 1 (one) week.

\section{b. Less time off}

Changes in working hours also have an impact on vacation time, namely only one day a week for 6 working days. In Article 79 paragraph $1 \mathrm{~b}$ of the Ciptaker Law, it is stated that the weekly rest period is only 1 day for 6 days a week. Meanwhile, in the Manpower Act, there is a weekly rest break for 1 (one) day for 6 (six) working days in 1 (one) week or 2 (two) days for 5 (five) working days in 1 (one) week.

\section{c. Minimum wage is lost}

Article 88 of the Ciptaker Law removes detailed provisions regarding the calculation of wages, namely that there is no longer a minimum wage provision. The calculation of wages will be based on the national wage policy as stipulated in government regulations. With this provision, the wages are potentially far from adequate. The provisions regarding the minimum wage in article 89 of the Manpower Act were also abolished by the Ciptaker Law . In addition, the fundamental change in wages in the Ciptaker Law is the calculation based on a unit of time. Although the time unit is not specified, the provision will have an impact on the hourly wages. With this calculation, automatically the minimum wage is no longer relevant for the provision of wages. In addition, the calculation of hourly wages will eliminate the wages that are usually received regularly per month.

\section{d. The wage calculation changes}

In the Job Creation Act, wages are calculated based on the unit of time and the unit of yield (productivity) contained in article 88B. In addition, wages are paid according to the company's ability and productivity, and there is no oversight of this matter. 


\section{e. Wages for Menstrual and Childbirth Leave will be lost}

The provisions of the Job Creation Act do not eliminate the articles in Law No. 13 of 2003 regarding menstrual leave and maternity leave. However, the substance of hourly wages eliminates the essence of menstrual leave and maternity leave because if female workers undergo such leave automatically they are not counted as working, so they do not get paid leave.

\section{f. Long leave is gone}

A number of leave such as long leave is no longer regulated by the government, but is regulated by the company with a work agreement, company regulations and a Collective Bargaining Agreement. If you are not careful and ready to negotiate and ask the company you work for, then your leave will be determined by the company unilaterally. Article 79 of the Ciptaker Law paragraph 5 also eliminates the right to long rest (long leave) for workers. Where, long leave is only determined by company regulations / work agreements, not the mandate of the law as stipulated in Law No. 13 of 2003.

\section{g. Unilateral layoffs are facilitated}

Companies can terminate employment (PHK) unilaterally through Article 154A of the Ciptaker Law, namely that dismissals can be made on the grounds that the company is merging, consolidating, taking over, or separating the company; efficiency; closed due to loss, force majeure, postponement of debt, and bankruptcy. Termination of employment is also made easier through article 151 of the Ciptaker Law which abolishes the provision "all efforts must be made to prevent termination of employment". Companies can also lay off workers without negotiating with the union. In addition, the Ciptakerja Law removes the provisions of Article 161 of the Manpower Law which previously regulated warning letters prior to dismissal. Therefore, companies can do layoffs without going through a warning letter mechanism.

\section{h. The amount of severance pay is reduced}

The provision in Article 156 of the Ciptaker Law reduces the amount of severance pay if a worker is laid off due to eliminating compensation for entitlements. In Article 156 of the Manpower Act, housing compensation as well as medical treatment and care are stipulated at $15 \%$ (fifteen percent) of the severance pay and / or service pay for those who meet the requirements. In addition, the Ciptaker Law eliminates articles 162-166 in the Manpower Act which detail the amount of severance pay and the calculation of service period rewards and compensation for workers who resign.

\section{Conclusion}

Labor According to Law no. 13 of 2003 Article 1 paragraph 2 states that: "A workforce is anyone who is capable of doing work in order to produce goods and / or services both to meet their own needs and for the community. Prior to the existence of the Job Creation Act, the omnibus law was classified as unfamiliar to the Indonesian public. This is reasonable, considering that the Job Creation Law is the first omnibus law passed in Indonesian law. The Omnibus Law itself became known to the public for the first time in the country since it was mentioned in President Jokowi's inauguration speech in his second term in October 2019. There is a difference of Law Copyright Labor Omnibus Law By Law Employment No. 13 of 2003. Law No.13 / 2003 does not state that workers for a certain time or contract workers are entitled or not to take annual leave, but it clearly 
stipulates in Article 79 paragraph (2) point c that workers are entitled to receive annual leave of at least 12 ( twelve) working days after the worker has worked for 12 (twelve). If a worker whose status is a worker for a certain time, and the contract period is more than 1 (one) year or is extended for a period of more than one year, the worker for this particular time is entitled to get annual leave. The right to leave between contract workers (PKWT) and the right to leave for permanent workers (PKWTT) both refer to the Manpower Act No. 13 of 2003 which explicitly regulates the issue of annual leave in Article 79 paragraph (2) letter c. and Article 79 paragraph (3). Based on Article 3 of Law Number 11 of 2020 concerning Job Creation, it is said that the purpose of the making of Law Number 11 of 2020 concerning Job Creation is to create the widest possible employment opportunities for the Indonesian people evenly. As for the Impact of the Omnibus Law on Society and Workers, namely:

1. Working hours and overtime are longer

2. Less time off

3. The minimum wage is lost

4. The calculation of wages has changed

5. Wages for Menstrual and Childbirth Leave will be lost

6. Missing sabbatical

7. Unilateral layoffs made easier

8. The amount of severance pay is reduced

From the description above, it is hoped that the Government is expected to regulate in more detail the points contained in the provisions of Law Number 13 of 2003 concerning manpower, such as differences in rights and obligations obtained by workers for a certain period of time, in order to better ensure legal protection in obtaining the rights that should can workers receive from the employer where they work, such as annual leave and compensation that should be received by workers because of the unilateral termination of employment.

\section{References}

Agus Midah, 2010, Hukum Ketenagakerjaan Indonesia Dinamika dan Kajian Teori, Bogor : Ghalia Indonesia,

Adhi Setyo Prabowo, Andhika Nugraha Triputra, Yoyok Junaidi, Didik Endro Purwoleksono. Politik Hukum Omnibus Law Di Indonesia. Vol 13, No 1. Jurnal Ilmiah Universitas Trunojoyo.

Bernat Panjaitan, 'Ousourcing (Alih Daya) Dan Pengelolaan Tenaga Kerja Pada Perusahaan (Tinjauan Yuridis Terhadap Undang-Undang Nomor 13 Tahun 2003 Tentang Ketenagakerjaan)', Jurnal Ilmiah Advokasi, 2016.

Dhaniswara K Hardjono Konsep Omnibus Law Ditinjau Dari Undang Undang No. 12 Tahun 2011 Tentang Pembentukan Peraturan Perundang Undangan. Jurnal Volume 6 No.2 Bulan Agustus 2020. http://ejournal.uki.ac.id/index.php/tora/article/view/1975 https://journal.trunojoyo.ac.id/pamator/article/view/6923

Jimly Asshiddiqie. Omnibus Law Dan Penerapannya Di Indonesia. Konstitusi Press.2021.

Kansil.C.S.T,Pengantar Ilmu Hukum dan Tata Hukum Indonesia,Penerbit Balai Pustaka.Jakarta.2002.

Khakim, Abdul, Pengantar Hukum Ketenagakerjaan Indonesia Berdasarkan UndangUndang No. 13 Tahun 2003, Bandung : PT. Citra Aditya Bakti, 2003.

Kitab Undang-Undang RI NO 13 Tahun 2003 Tentang Ketenagakerjaan dan UndangUndang RI NO 21 Tahun 2000 Tentang Serikat Buruh.Kesindo Utama, Surabaya. 
Pidato

Presiden

Jokowidodo

artikel

https://nasional.kompas.com/read/2020/10/20/06255981/setahun-jokowi-danpidatonya-soal-omnibus-law-ruu-cipta-kerja

Prinst, Darwan, Hukum Ketenagakerjaan Indonesia, Bandung : PT. Citra Aditya Bakti, 2000

Soepomo, Iman, Pengantar Hukum Perburuhan, Jakarta : Djambatan, 2003.

Soerjono Soekanto dan Sr Mahmudji, Penelitian Hukum Normatif, Suatu Tinjauan Sinkat, Jakarta. Raja Grafindo Persada, (2003).

Tujuan dan Manfaat Omnius Law artikel https://www.talenta.co/blog/insight-talenta/poinpoin-uu-omnibus-law-cipta-kerja-yang-disahkan/

Undang-Undang NO 11 Tahun 2020 Tentang Cipta Kerja

Undang - Undang NO 13 Tahun 2003 Tentang Ketenagakerjaan

Undang-Undang RI NO 21 Tahun 2000 Tentang Serikat Buruh 